Article

\title{
Hydrogen Sulfide Affects the Root Development of Strawberry During Plug Transplant Production
}

\author{
Jiangtao Hu ${ }^{1,+}$, Yali $\mathrm{Li}^{1,+}$, Ya Liu ${ }^{1} \mathbb{C}$, Dong Il Kang ${ }^{1}$, Hao Wei ${ }^{1}$ and Byoung Ryong Jeong ${ }^{1,2,3, * \mathbb{C}}$ \\ 1 Department of Horticulture, Division of Applied Life Science (BK21 Plus Program), Graduate School of \\ Gyeongsang National University, Jinju 52828, Korea; hujiangtao@gnu.ac.kr (J.H.); leeyali@gnu.ac.kr (Y.L.); \\ liuya113@mails.ucas.ac.cn (Y.L.); kinll01@gnu.ac.kr (D.I.K.); oahiew@gnu.ac.kr (H.W.) \\ 2 Institute of Agriculture and Life Science, Gyeongsang National University, Jinju 52828, Korea \\ 3 Research Institute of Life Science, Gyeongsang National University, Jinju 52828, Korea \\ * Correspondence: brjeong@gnu.ac.kr; Tel.: +82-55-772-1913 \\ + These authors contributed equally to this work.
}

Received: 7 December 2019; Accepted: 3 January 2020; Published: 5 January 2020

check for updates

\begin{abstract}
Hydrogen sulfide $\left(\mathrm{H}_{2} \mathrm{~S}\right)$ is endogenously produced in plant cells and plays an essential role in root development. Given its potential for future agricultural applications, the optimal concentration of sodium hydrosulfide (NaHS, an $\mathrm{H}_{2} \mathrm{~S}$ donor) and the potential mechanisms for root development in the strawberry 'Seolhyang' were investigated in this study. The results showed that NaHS with a concentration of $1.250 \mathrm{mM}$ had a positive effect on root development in strawberry. Further experiments showed that exogenous NaHS elevated the $\mathrm{H}_{2} \mathrm{~S}$ content in the root. The dry root weight was increased by the $1.250 \mathrm{mM}$ NaHS treatment, but was reduced by the hypotaurine (an $\mathrm{H}_{2} \mathrm{~S}$ scavenger) treatment. Similar changes were found between $\mathrm{H}_{2} \mathrm{~S}$ and soluble sugar contents, indicating that $\mathrm{H}_{2} \mathrm{~S}$ enhanced the accumulation of soluble sugar. Therefore, it is suggested that the accumulation of soluble sugar induced by $\mathrm{H}_{2} \mathrm{~S}$ is either directly or indirectly involved in root development in strawberry during plug production. Moreover, superoxide dismutase was shown to have contributed to the elevated $\mathrm{H}_{2} \mathrm{O}_{2}$ contents. These results contribute to our understanding of the role that $\mathrm{H}_{2} \mathrm{~S}$ plays and some of the relevant mechanisms in which $\mathrm{H}_{2} \mathrm{~S}$ regulates root development.
\end{abstract}

Keywords: antioxidant enzyme; hydrogen peroxide; hydrogen sulfide; root development; soluble sugar

\section{Introduction}

Runner tips have been widely used to produce strawberry plug transplants because of their advantages, which include their reduced pesticide requirements and soil-borne diseases, ease of transplanting, and low water requirements [1]. A well-rooted plant is essential for shipping, transplanting, and special conditioning. Studies have been conducted to determine the optimal cell-tray sizes [2], rooting media [3], and temperatures [4,5] for root development in strawberry. Moreover, the rooting time was found to affect the plant morphology. Early-rooted strawberry plants had more nodes, runners, and higher total fresh and dry weights [6]. In Korea, farmers propagate strawberry plants in both the summer and winter. The root development is adversely affected by the low temperature in winter. Therefore, it is important to explore a variety of strategies to obtain high-quality transplants.

Hydrogen sulfide $\left(\mathrm{H}_{2} \mathrm{~S}\right)$ has been studied as a gaseous transmitter for the roles it plays in plant growth, development, and tolerance to biotic and abiotic stresses. $\mathrm{H}_{2} \mathrm{~S}$ can be synthesized via enzymatic reactions in plant cells or be absorbed from the rhizosphere. It has been reported that $\mathrm{H}_{2} \mathrm{~S}$ inhibits the primary root elongation, but promotes the lateral root initiation, in Arabidopsis [7]. The positive effects 
of $\mathrm{H}_{2} \mathrm{~S}$ on root formation in tomato [8-10] and cucumber [11] have also been reported. In strawberry, $\mathrm{H}_{2} \mathrm{~S}$ has been shown to prolong the postharvest shelf life $[12,13]$ and induce systemic tolerances to heat, salinity, and non-ionic osmotic stresses [14,15]. However, the roles of $\mathrm{H}_{2} \mathrm{~S}$ in the root development of strawberry have not yet been identified. Furthermore, the concentrations of $\mathrm{H}_{2} \mathrm{~S}$ used for horticultural crops have ranged from $0.2 \mu \mathrm{M}$ to $10 \mathrm{mM}$ in previous studies [16]. The optimal concentration of $\mathrm{H}_{2} \mathrm{~S}$ for root development in strawberry has not been established.

Rooting is a physiological process of high energy demands, which requires high carbohydrate, starch, and protein contents [17-20]. It has been shown that the number of roots increased in a sugarcane bagasse medium in in-vitro propagated strawberry [21]. Moreover, it has been observed that $\mathrm{H}_{2} \mathrm{~S}$ increases the soluble sugar content by up-regulating the genes involved in the synthesis of sugar [22]. Therefore, the soluble sugar, starch, and soluble protein contents were investigated as they are appropriate indicators of the rooting capacity.

Numerous studies have addressed the roles of antioxidant enzymes in rooting [23-26]. In an enzymatic anti-oxidant system, superoxide dismutase (SOD) converts superoxide ions to hydrogen peroxide $\left(\mathrm{H}_{2} \mathrm{O}_{2}\right)$. The $\mathrm{H}_{2} \mathrm{O}_{2}$ is scavenged by peroxidases such as glutathione peroxidase (GPX), catalase (CAT), and ascorbate peroxidase (APX). Although higher concentrations of $\mathrm{H}_{2} \mathrm{O}_{2}$ cause oxidative damage in plant cells, $\mathrm{H}_{2} \mathrm{O}_{2}$ in low concentrations can serve important biological roles in cell division, differentiation, and migration [27]. The involvement of $\mathrm{H}_{2} \mathrm{O}_{2}$ in root development has been reported in tomato [10], mung bean [28,29], and cucumber seedlings [30].

Multiple $\mathrm{H}_{2} \mathrm{~S}$ donors are currently being studied for their potential uses in biological and clinical applications [31]. Given the potential for future commercial applications, we sought to investigate the optimal concentration and effects of sodium hydrosulfide (NaHS) on the root development in strawberry. The results of this study may also help to elucidate the role that $\mathrm{H}_{2} \mathrm{~S}$ plays in regulating root development.

\section{Materials and Methods}

\subsection{Plant Materials and Chemical Treatments}

Unrooted runner plants of the strawberry (Fragaria $\times$ ananassa Duch.) 'Seolhyang' were used in this study. For experiment 1 , the runner plants with $20 \mathrm{~cm}$ long and three fully expanded leaves were obtained from a strawberry farm (Sugok-myeon, Jinju, Gyeongsangnam-do, Korea) and stuck in a BVB Medium (Bas Van Buuren Substrates, EN-12580, De Lier, The Netherlands) containing NaHS $\left(0.010,0.125,0.250,1.250,2.500,12.500,25.000\right.$, and $37.500 \mathrm{mM}$; an $\mathrm{H}_{2} \mathrm{~S}$ donor) or distilled water (the control) in 21-cell zigzag trays (21-Zigpot/21 cell tray, Daeseung, Jeonju, Korea). Experiment 1 was conducted in December of 2017, and the mean air temperature was $10{ }^{\circ} \mathrm{C}$. For experiment 2 , the runner plants with $15 \mathrm{~cm}$ long and three fully expanded leaves were stuck and grown in a BVB Medium containing $0.125,1.250$, and $12.500 \mathrm{mM}$ of $\mathrm{NaHS} ; 50 \mu \mathrm{M}$ of hypotaurine (HT, an $\mathrm{H}_{2} \mathrm{~S}$ scavenger); or distilled water (the control). Experiment 2 was conducted in December of 2018, and the mean air temperature was $15{ }^{\circ} \mathrm{C}$. Plants were kept on a mist propagation bench with a relative humidity of $80 \%$ for 10 days, followed by cultivation in a glasshouse at Gyeongsang National University, Jinju, Korea, for another 10 days. The experiment was conducted based on a completely randomized design with three replicates and each replicate contained seven runner plants. The plants were treated again with the chemicals mentioned above one day before measuring and sampling.

\subsection{Measurement of Root Development and Sampling}

The substrate was washed to expose the roots. The number of roots, length of the longest root, and fresh root weight were then measured. The root dry weight was measured after drying the roots in an oven at $65^{\circ} \mathrm{C}$ for 3 days. The roots were immersed in liquid nitrogen and ground into a fine powder for the subsequent analyses. 


\section{3. $\mathrm{H}_{2} \mathrm{~S}$ and $\mathrm{H}_{2} \mathrm{O}_{2}$ Quantification}

The $\mathrm{H}_{2} \mathrm{~S}$ level was measured according to the method introduced by Nashef et al. [32]. In brief, $0.2 \mathrm{~g}$ of root samples was homogenized in $1 \mathrm{~mL}$ of a $100 \mathrm{mM}$ potassium phosphate buffer $(\mathrm{pH} 7.0)$ containing $10 \mathrm{mM}$ of ethylenediaminetetraacetic acid and then centrifuged at $13,000 \mathrm{~g}$ for $15 \mathrm{~min}$ at $4{ }^{\circ} \mathrm{C}$. The reaction mixture was made in a total volume of $2 \mathrm{~mL}$ containing with $100 \mu \mathrm{L}$ of the supernatant, $20 \mu \mathrm{L}$ of $20 \mathrm{mM}$ 5,5'-dithiobis (2-nitrobenzoic acid), and $1880 \mu \mathrm{L}$ of extraction buffer. The absorbance was read at $412 \mathrm{~nm}$ after incubating the mixture at room temperature for $2 \mathrm{~min}$. The $\mathrm{H}_{2} \mathrm{~S}$ content was quantified based on a standard curve of known NaHS concentrations. $\mathrm{H}_{2} \mathrm{O}_{2}$ quantification was performed as described by Loreto and Velikova [33]. In brief, $0.2 \mathrm{~g}$ of root samples was homogenized in $1 \mathrm{~mL}$ of $0.1 \%(w / v)$ trichloroacetic acid and then centrifuged at $13,000 \mathrm{~g}$ for $15 \mathrm{~min}$ at $4{ }^{\circ} \mathrm{C}$. The reaction mixture was made in a total volume of $2 \mathrm{~mL}$ containing $0.5 \mathrm{~mL}$ of the supernatant, $0.5 \mathrm{~mL}$ of $10 \mathrm{mM}$ potassium phosphate buffer ( $\mathrm{pH} 7.0)$, and $1 \mathrm{~mL}$ of $1 \mathrm{M}$ potassium iodide. The absorbance of the mixture was read at $390 \mathrm{~nm}$. The $\mathrm{H}_{2} \mathrm{O}_{2}$ content was calculated based on a standard curve of known $\mathrm{H}_{2} \mathrm{O}_{2}$ concentrations.

\subsection{Measurements of Soluble Sugar, Starch, and Soluble Protein Contents}

Soluble sugar and starch contents were measured via the anthrone-sulfuric acid method introduced by Xue et al. [34]. In brief, $0.3 \mathrm{~g}$ of root samples was homogenized with $25 \mathrm{~mL}$ of distilled water to extract the soluble sugar, and the residue was homogenized with $20 \mathrm{~mL}$ of distilled water and $2 \mathrm{~mL}$ of $9.2 \mathrm{M}$ perchloric acid for measurement of the starch content. The contents of soluble sugar and starch were calculated based on a standard curve of known concentrations of sucrose and starch, respectively.

Soluble protein was measured using a Bradford Reagent Kit (Sigma-Aldrich, St. Louis, MO, USA), according to the manual. The soluble protein content was calculated based on a standard curve of a known concentration of bovine serum albumin.

\subsection{Determination of the Antioxidant Enzyme Activities}

The activities of antioxidant enzymes SOD, GPX, CAT, and APX were determined by the method introduced by Manivannan et al. [35]. In brief, samples were ground in a $100 \mathrm{mM}$ sodium phosphate buffer ( $\mathrm{pH}$ 7.0) for the GPX activity assay and in a $50 \mathrm{mM}$ sodium phosphate buffer ( $\mathrm{pH} 7.0)$ containing $1 \mathrm{mM}$ of ethylenediaminetetraacetic acid, $0.05 \%$ Triton $\mathrm{X} 100$, and $2 \%$ polyvinylpyrrolidone for SOD, CAT, and APX activity assays. The SOD assay was made in a total volume of $3.0 \mathrm{~mL}$ containing $2.5 \mathrm{~mL}$ of sodium phosphate buffer $(50 \mathrm{mM}), 0.4 \mathrm{~mL}$ of riboflavin $(2 \mathrm{mM})$, and $0.1 \mathrm{~mL}$ of enzyme extract. The GPX assay was made in a total volume of $3.00 \mathrm{~mL}$ containing $2.80 \mathrm{~mL}$ of sodium phosphate buffer $(50 \mathrm{mM}), 0.05 \mathrm{~mL}$ of guaiacol $(20 \mathrm{mM}), 0.05 \mathrm{~mL}$ of $\mathrm{H}_{2} \mathrm{O}_{2}(30 \mathrm{mM})$, and $0.10 \mathrm{~mL}$ of enzyme extract. The CAT assay was made in a total volume of $3.0 \mathrm{~mL}$ containing $2.8 \mathrm{~mL}$ of sodium phosphate buffer (50 mM), $0.1 \mathrm{~mL}$ of $\mathrm{H}_{2} \mathrm{O}_{2}(30 \mathrm{mM})$, and $0.10 \mathrm{~mL}$ of enzyme extract. The APX assay was made in a total volume of $3.0 \mathrm{~mL}$ containing $2.8 \mathrm{~mL}$ of sodium phosphate buffer $(50 \mathrm{mM}$ containing $0.5 \mathrm{mM}$ of ascorbic acid), $0.1 \mathrm{~mL}$ of $\mathrm{H}_{2} \mathrm{O}_{2}(30 \mathrm{mM})$, and $0.10 \mathrm{~mL}$ of enzyme extract. The specific enzyme activity was represented as the unit $\mu \mathrm{g}^{-1}$ protein.

\subsection{Statistical Analysis}

After the normality and homoscedasticity of data were verified, the SAS statistical software, Release 8.2 (SAS Inst., Cary. N.C., USA), was used for the statistical analysis, followed by an analysis of variance (ANOVA) and Duncan's multiple range test $(p \leq 0.05)$. 


\section{Results}

\subsection{The Optimal Concentration of NaHS for Strawberry (Experiment 1)}

$\mathrm{NaHS}$ at appropriate concentrations promoted the root development in strawberry runner plants (Figure 1A). The length of the longest root was increased significantly by the $0.250,1.250$, and $2.500 \mathrm{mM}$ NaHS treatments compared to that of the control ( $p \leq 0.05$; Figure $1 C)$. The dry weights of the roots were significantly increased by the $1.250 \mathrm{mM}$ NaHS treatment ( $p \leq 0.05$; Figure 1D,E). Even though the mean values of the number of roots and fresh weight of roots were highest in the $2.500 \mathrm{mM}$ NaHS treatment and $1.250 \mathrm{mM}$ NaHS treatment, respectively, there were no statistically significant differences (Figure 1B,C). Overall, the exogenous NaHS at the concentration of $1.250 \mathrm{mM}$ had an overall positive effect on the root development, and was selected as the optimal concentration for the following experiments.
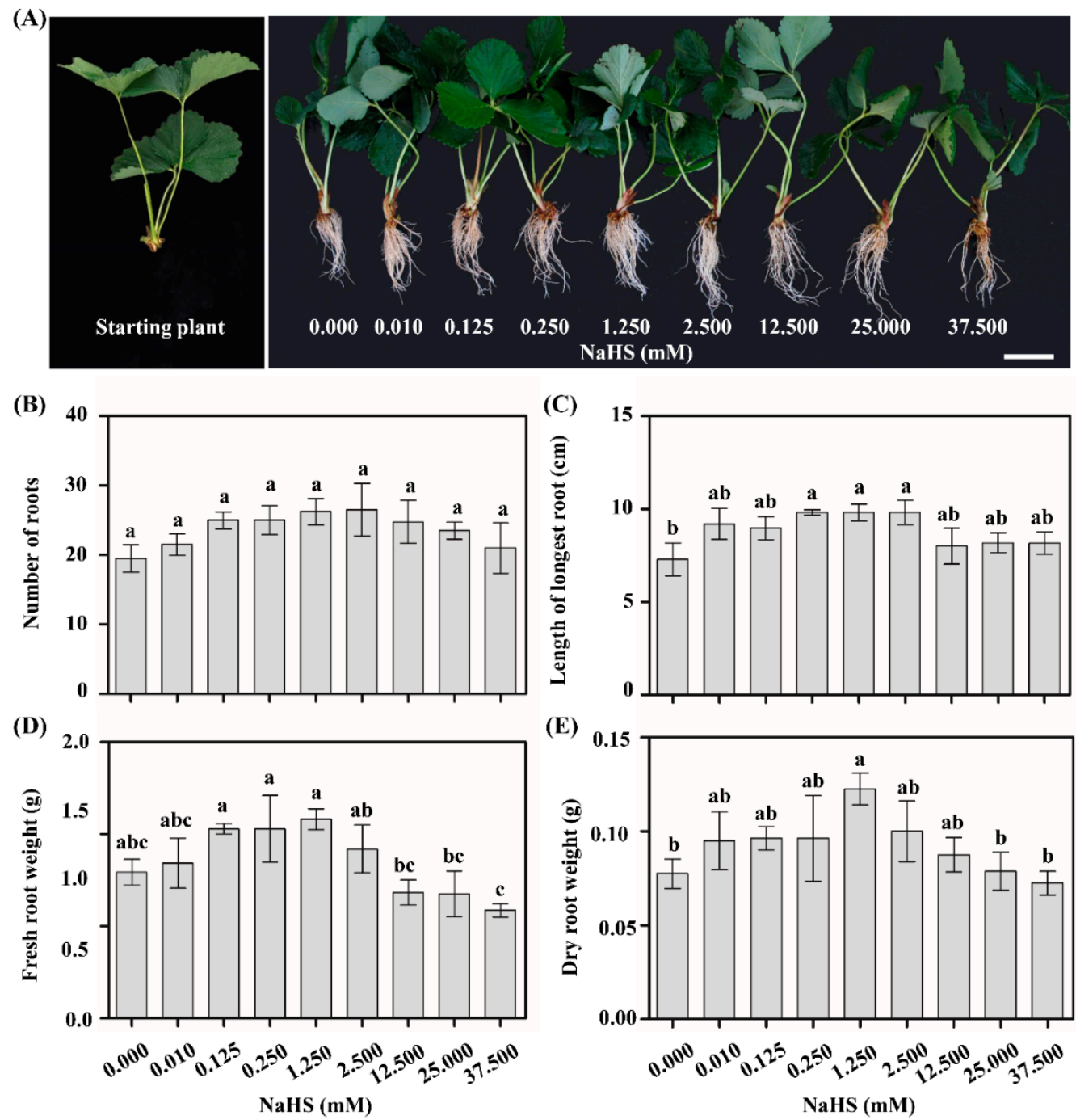

Figure 1. The effects of different sodium hydrosulfide (NaHS) concentrations (mM) on the morphology (A), number of roots (B), length of the longest root (C), fresh root weight (D), and dry root weight (E) of strawberry runner plants. The data were collected 20 days after the first treatment and are represented as the mean \pm S.E of six biological replicates. Means accompanied by different letters are significantly different according to Duncan's multiple range test at a $5 \%$ significance level. Scale bar $=5 \mathrm{~cm}$. 


\subsection{Root Development Induced by $\mathrm{H}_{2} \mathrm{~S}$ (Experiment 2)}

The runner plants were treated with $\mathrm{HT}, \mathrm{H}_{2} \mathrm{O}$, and NaHS to investigate the effects of $\mathrm{H}_{2} \mathrm{~S}$ on the root development (Figure 2A). The $\mathrm{H}_{2} \mathrm{~S}$ content in strawberry was significantly elevated with the $1.250 \mathrm{mM}$ NaHS treatment, but significantly reduced with the $12.500 \mathrm{mM}$ NaHS treatment $(p \leq 0.05)$, compared to that for the HT treatment and the control (Figure 2B).

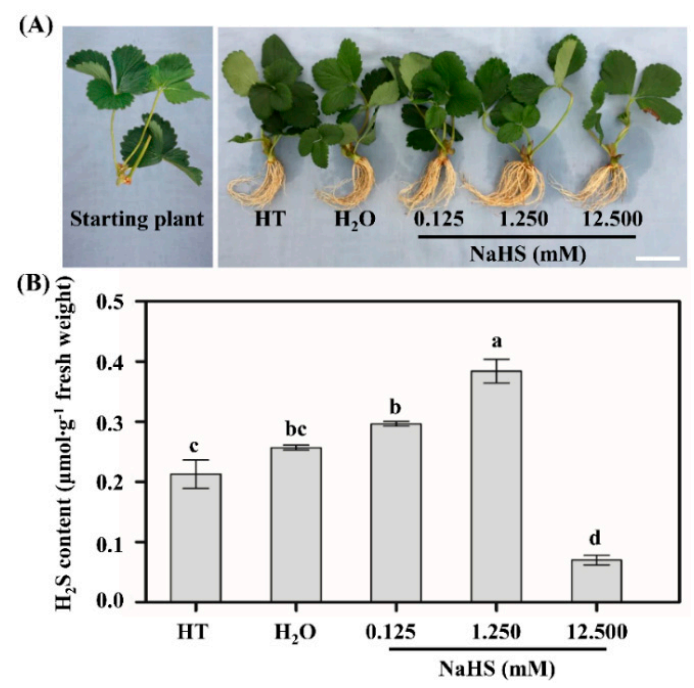

Figure 2. The effects of hypotaurine (HT), $\mathrm{H}_{2} \mathrm{O}$, and $\mathrm{NaHS}$ on the morphology (A) and $\mathrm{H}_{2} \mathrm{~S}$ content (B) of strawberry runner plants. The data were collected 20 days after the first treatment and are represented as the mean \pm S.E of three biological replicates and three technical replicates. Means accompanied by different letters are significant differences according to Duncan's multiple range test at a $5 \%$ significance level. Scale bar $=5 \mathrm{~cm}$.

Correspondingly, as the $\mathrm{H}_{2} \mathrm{~S}$ content increased, the fresh and dry weights of roots also increased (Figure 3C,D). However, the number of roots and length of the longest root in the HT and the NaHS treatments showed no significant differences compared with the control ( $p \leq 0.05$; Figure $3 \mathrm{~A}, \mathrm{~B})$.
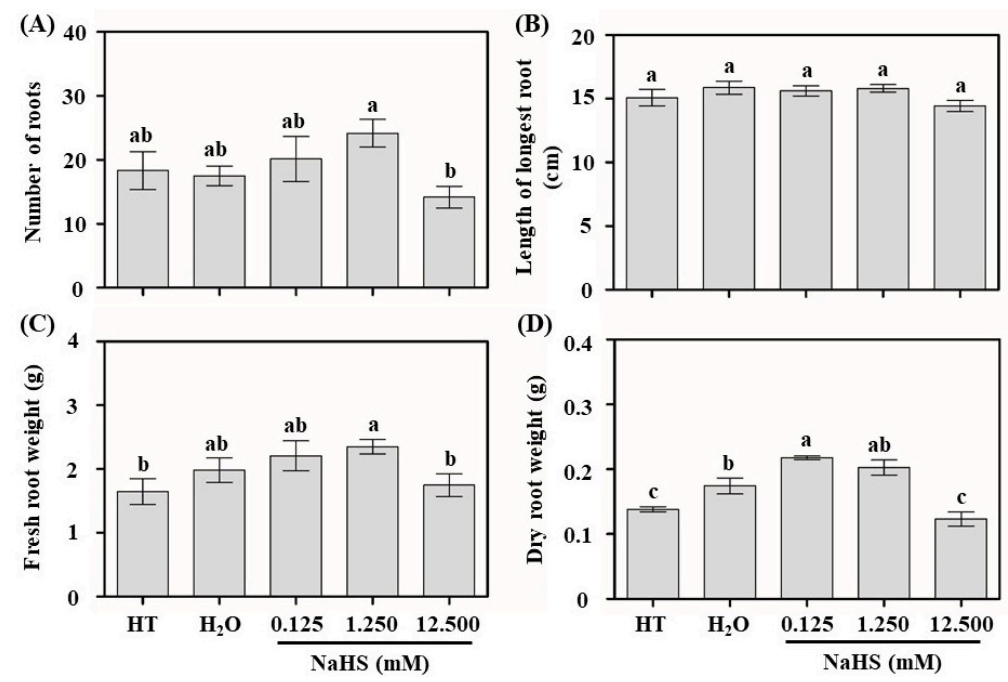

Figure 3. The effects of $\mathrm{HT}, \mathrm{H}_{2} \mathrm{O}$, and NaHS on the number of roots (A), length of the longest root (B), fresh root weight $(\mathbf{C})$, and dry root weight $(\mathbf{D})$ in strawberry runner plants. The data were collected 20 days after the first treatment and are represented as the mean \pm S.E of six biological replicates. Means accompanied by different letters are significant differences according to Duncan's multiple range test at a $5 \%$ significance level. 


\subsection{Soluble Sugar, Starch, and Soluble Protein Content}

The soluble sugar content was significantly increased by the 0.125 and $1.250 \mathrm{mM} \mathrm{NaHS}$ treatments $(p \leq 0.05$, Figure $4 \mathrm{~A}$ ). The starch and soluble protein contents in the roots of strawberry runner plants showed no significant variations among the treatments (Figure $4 \mathrm{~B}, \mathrm{C}$ ).
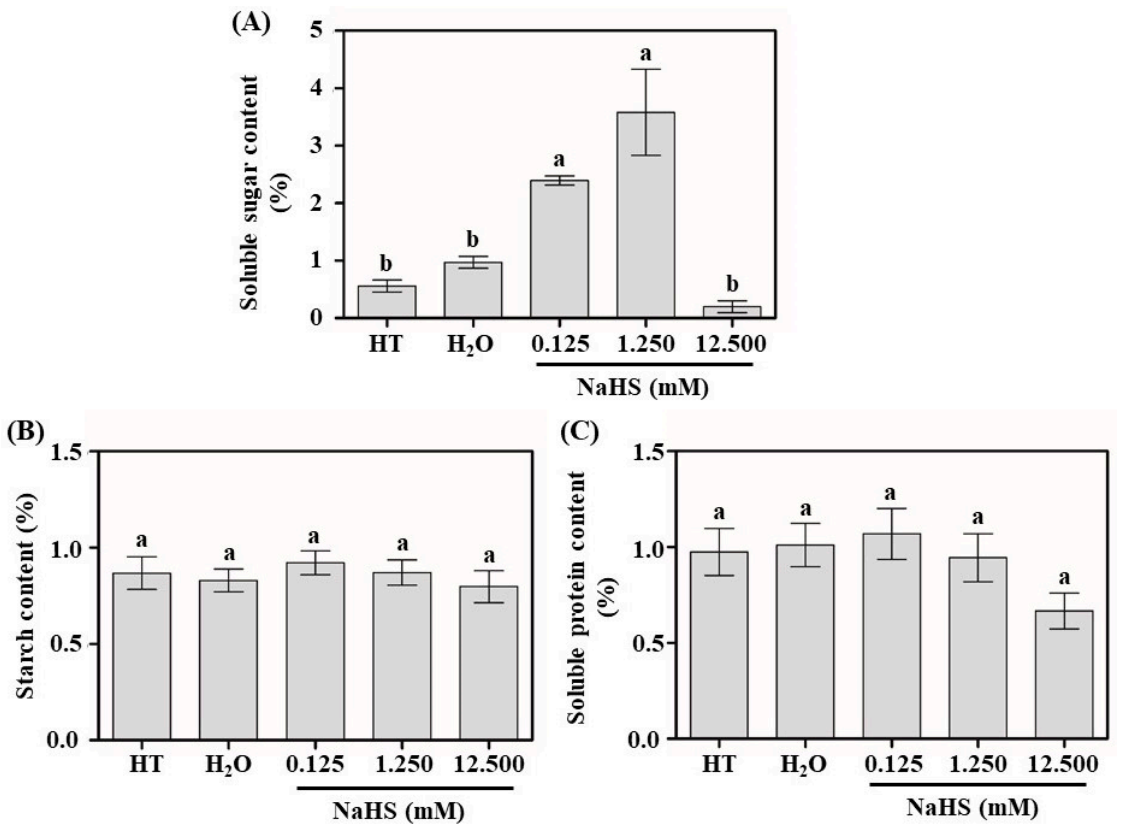

Figure 4. The effects of $\mathrm{HT}, \mathrm{H}_{2} \mathrm{O}$, and $\mathrm{NaHS}$ on the soluble sugar (A), starch (B) and soluble protein (C) contents in the roots of strawberry runner plants. Samples were collected 20 days after the first treatment, and the data are represented as the mean \pm S.E of three biological replicates and three technical replicates. Means accompanied by different letters are significant differences according to Duncan's multiple range test at a 5\% significance level.

\section{4. $\mathrm{H}_{2} \mathrm{O}_{2}$ Content}

The $\mathrm{H}_{2} \mathrm{O}_{2}$ contents in the roots of strawberry runner plants were significantly increased by the 0.125 and $1.250 \mathrm{mM} \mathrm{NaHS}$ treatments, compared to that in the HT treatment $(p \leq 0.05)$. However, no significant differences were found in the roots of strawberry runner plants grown in the 0.125 and $1.250 \mathrm{mM} \mathrm{NaHS}$ treatments and in the control (Figure 5).

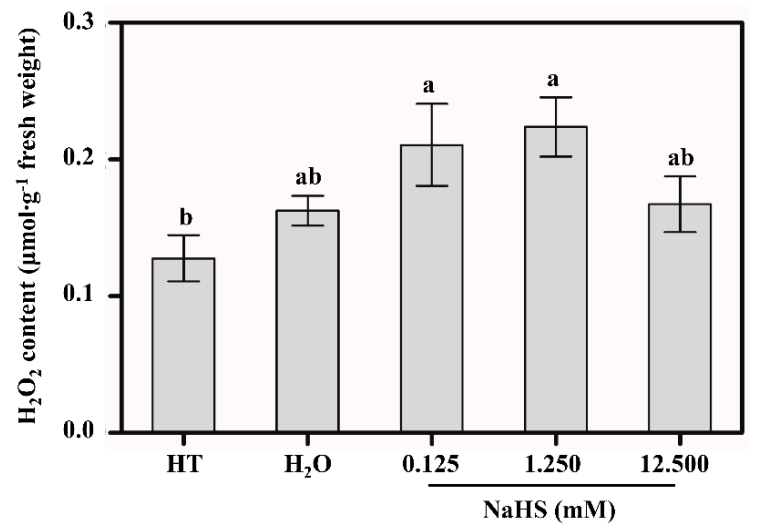

Figure 5. The effects of $\mathrm{HT}, \mathrm{H}_{2} \mathrm{O}$, and $\mathrm{NaHS}$ on the $\mathrm{H}_{2} \mathrm{O}_{2}$ content in the roots of strawberry runner plants. Samples were collected 20 days after the first treatment, and the data are represented as the mean \pm S.E of three biological replicates and three technical replicates. Means accompanied by different letters are significant differences according to Duncan's multiple range test at a 5\% significance level. 


\subsection{Antioxidant Enzyme Activities}

The SOD activity in the roots of strawberry runner plants was significantly increased by the 0.125 treatment compared to that in the HT treatment ( $p \leq 0.05$, Figure 6A). The GPX activity was the highest in the HT treatment and the lowest in the $12.500 \mathrm{mM} \mathrm{NaHS}$ treatment (Figure 6B). The CAT activity was significantly inhibited by the HT and NaHS treatments compared to the control $(p \leq 0.05$, Figure 6C). The APX activity was not significantly changed by different treatments (Figure 6D).
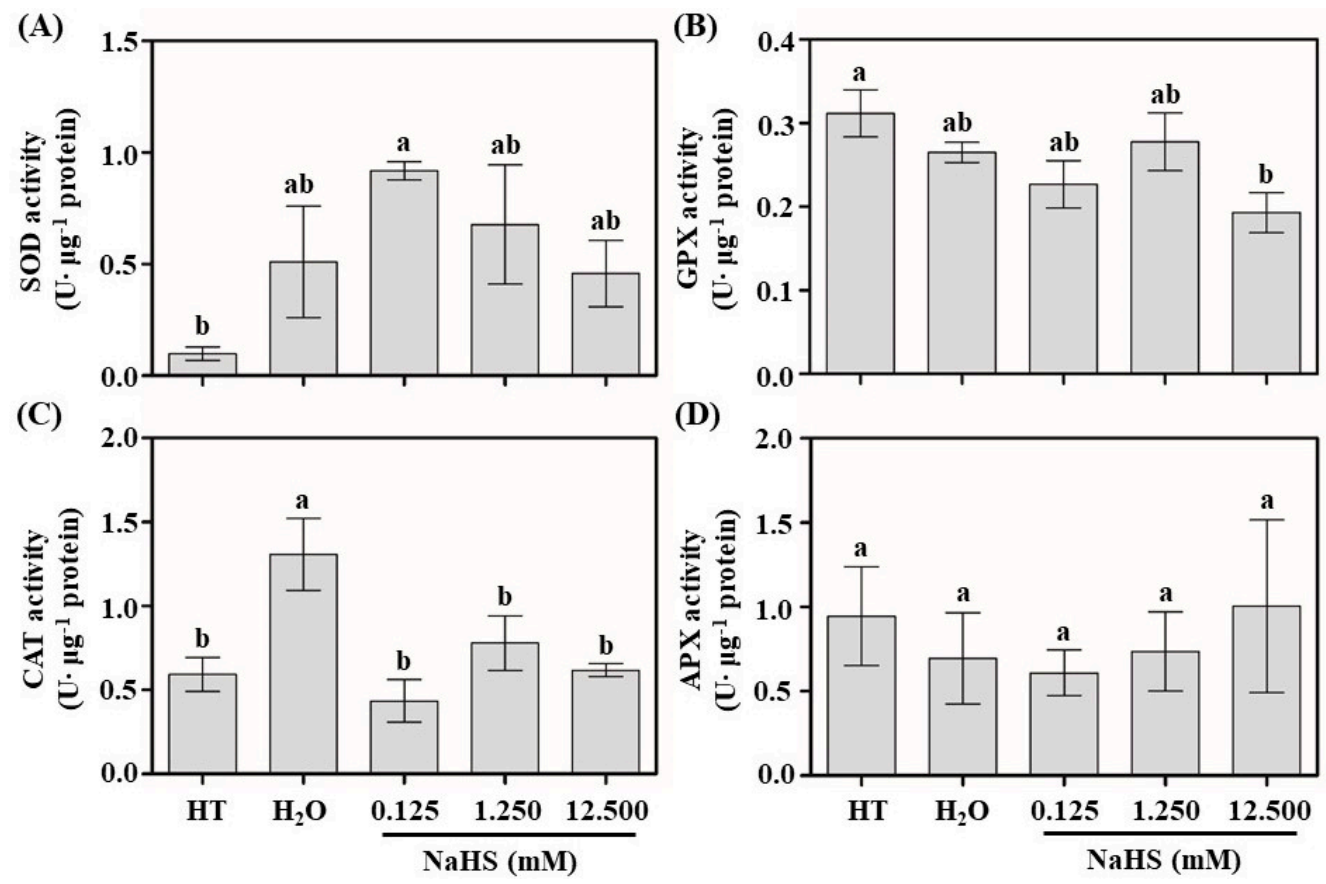

Figure 6. The effects of $\mathrm{HT}, \mathrm{H}_{2} \mathrm{O}$, and $\mathrm{NaHS}$ on the activity of superoxide dismutase (SOD) (A), glutathione peroxidase (GPX) (B), catalase (CAT) (C), and ascorbate peroxidase (APX) (D) in the roots of strawberry runner plants. Samples were collected 20 days after the first treatment, and the data are represented by the mean \pm S.E of three biological replicates and three technical replicates. Means accompanied by different letters are significant differences according to Duncan's multiple range test at a $5 \%$ significance level.

\section{Discussion and Conclusions}

$\mathrm{H}_{2} \mathrm{~S}$ can be endogenously generated in plant cells or obtained from water-soluble donors such as $\mathrm{NaHS}$. Endogenous $\mathrm{H}_{2} \mathrm{~S}$ has beneficial effects on plant growth and defense responses [16,36]. Several investigators have used concentrations between 0.010 and $10.000 \mathrm{mM}$ of NaHS to evaluate the effects of $\mathrm{H}_{2} \mathrm{~S}$ on the root development in cucumber and tomato [8,37]. In our study, the root development in strawberry was promoted by the $1.250 \mathrm{mM} \mathrm{NaHS}$ treatment. Moreover, the $\mathrm{H}_{2} \mathrm{~S}$ content in the roots of strawberry ranged from 0.26 (the control) to 0.38 (1.250 mM NaHS treatment) $\mu \mathrm{mol} \cdot \mathrm{g}^{-1}$ fresh weight. In the roots of Arabidopsis, the $\mathrm{H}_{2} \mathrm{~S}$ content was about 0.02 and $0.23 \mu \mathrm{mol} \cdot \mathrm{g}^{-1}$ fresh weight in the control and $1.000 \mathrm{mM} \mathrm{NaHS}$ treatment, respectively [7]. In the roots of tomato, the highest $\mathrm{H}_{2} \mathrm{~S}$ content was observed nine hours after the treatments, when it was about 0.70 (the control) and 1.80 (100 nM naphthalene acetic acid treatment) $\mu \mathrm{mol} \cdot \mathrm{g}^{-1}$ fresh weight. Twelve hours after the treatments, the $\mathrm{H}_{2} \mathrm{~S}$ content decreased to approximately 0.50 (the control) and $0.60(100 \mathrm{nM}$ naphthalene acetic acid treatment) $\mu \mathrm{mol} \cdot \mathrm{g}^{-1}$ fresh weight [8]. In summary, the endogenous concentrations of $\mathrm{H}_{2} \mathrm{~S}$ in the roots of plants are found to be approximate based on the published data.

Since the $\mathrm{H}_{2} \mathrm{~S}$ content can be increased initially and then decreased after the NaHS treatments, the plants were treated again with chemicals one day before sampling. It was found that the $\mathrm{H}_{2} \mathrm{~S}$ content was significantly increased by the $1.250 \mathrm{mM} \mathrm{NaHS}$ treatment, while there was no significant difference 
between the HT treatment and the control. As the dry root weight was significantly decreased by the HT treatment, it is suggested that temporal changes of $\mathrm{H}_{2} \mathrm{~S}$ content in the HT treatment need to be further investigated. In addition, the results of two experiments were inconsistent. For example, the length of the longest root was significantly increased in the $1.250 \mathrm{mM} \mathrm{NaHS}$ treatment in experiment 1 , while there were no significant differences between the $1.250 \mathrm{mM} \mathrm{NaHS}$ treatment and the control in experiment 2 . This might have been caused by the different air temperatures at the time when the experiments were conducted.

The soluble sugar content in strawberry root was increased by the 0.125 and $1.250 \mathrm{mM} \mathrm{NaHS}$ treatments, which is consistent with the $\mathrm{H}_{2} \mathrm{~S}$ content in different treatments. However, the starch and soluble protein contents were not affected by the treatments. These results indicate that soluble sugar accumulation might be induced by $\mathrm{H}_{2} \mathrm{~S}$ in the roots of strawberry. It has been revealed that $\mathrm{H}_{2} \mathrm{~S}$ up-regulates sugar biosynthesis-related genes, such as sucrose phosphate synthase (SPS1), fructose-1,6-bisphosphatase (FBPase), and trehalose-6-phosphate synthase (T6PS), under drought stress in Spinacia oleracea seedlings [22]. In addition, soluble sugar changes the genes and metabolites involved in the indole-3-acetic acid (IAA) biosynthetic pathways [38]. Therefore, soluble sugar might be induced by $\mathrm{H}_{2} \mathrm{~S}$ through a change of sugar biosynthesis-related genes, and further promotes the root development by inducing IAA biosynthesis.

The $\mathrm{H}_{2} \mathrm{O}_{2}$ content and SOD activity were promoted by the $0.125 \mathrm{mM} \mathrm{NaHS}$ treatment compared with the HT treatment. Therefore, the SOD activity might have contributed to the accumulation of $\mathrm{H}_{2} \mathrm{O}_{2}$ [39]. Studies have reported that $\mathrm{H}_{2} \mathrm{~S}$ contributes to higher activities of reactive oxygen species (ROS)-scavenging enzymes under abiotic stress [40-42]. In this study, the CAT activity in the roots of strawberry runner plants was inhibited in the NaHS treatments, and it was also inhibited in the HT treatment compared to the control. Therefore, the change of CAT activity in the roots of strawberry runner plants might not be caused by $\mathrm{H}_{2} \mathrm{~S}$. Moreover, the GPX and APX activities in the roots of strawberry runner plants showed no significant differences among the treatments. Therefore, it could be deduced that $\mathrm{H}_{2} \mathrm{O}_{2}$ was in physiological concentrations, and thus did not activate the peroxidases.

In this study, the contents of $\mathrm{H}_{2} \mathrm{~S}$, soluble sugar, and $\mathrm{H}_{2} \mathrm{O}_{2}$ reached optimal concentrations only after the application of $1.250 \mathrm{mM}$ NaHS. The $12.500 \mathrm{mM} \mathrm{NaHS}$ treatment significantly decreased the dry weight of roots compared with the $1.250 \mathrm{mM} \mathrm{NaHS}$ treatment. Therefore, high concentrations of NaHS might have interfered with the metabolism of strawberry plants. Multiple studies have also reported the toxic effect of NaHS at high concentrations [43-45]. Moreover, the concentrations of NaHS applied in this study should decrease over time due to fogging, and the plants were treated again with chemicals one day before sampling. It is a shortcoming that we failed to determine the final concentrations of NaHS.

Overall, soluble sugar and $\mathrm{H}_{2} \mathrm{O}_{2}$ accumulation was found to be induced by $\mathrm{H}_{2} \mathrm{~S}$. It could be deduced that both types of accumulation are either directly or indirectly involved in the root development in strawberry during plug transplant production. Further works are needed to investigate the temporal changes of metabolism and biochemistry, as well as the genes that are involved in the interplay of $\mathrm{H}_{2} \mathrm{~S}$ and $\mathrm{H}_{2} \mathrm{O}_{2}$ signaling when plants are treated with $\mathrm{NaHS}$.

Author Contributions: Conceptualization, B.R.J. and Y.L. (Ya Liu); methodology, B.R.J. and J.H.; formal analysis, J.H. and Y.L. (Yali Li); resources, B.R.J.; data curation, J.H., Y.L. (Yali Li), D.I.K., and H.W.; writing-original draft preparation, J.H.; writing - review and editing, B.R.J.; project administration, B.R.J.; funding acquisition, B.R.J., D.I.K., H.W., J.H., and Y.L. (Yali Li). All authors have read and agreed to the published version of the manuscript.

Funding: This research was funded by the Agrobio-Industry Technology Development Program, Ministry of Food, Agriculture, Forestry and Fisheries, Republic of Korea (Project No. 315004-5).

Acknowledgments: This study was supported by the Agrobio-Industry Technology Development Program, Ministry of Food, Agriculture, Forestry and Fisheries, Republic of Korea (Project No. 315004-5). Jiangtao Hu, Yali Li, Ya Liu, Dong Il Kang, and Hao Wei were supported by the BK21 Plus Program, Ministry of Education, Korea.

Conflicts of Interest: The authors declare no conflicts of interest. 


\section{References}

1. Durner, E.F.; Poling, E.B.; Maas, J.L. Recent advances in strawberry plug transplant technology. HortTechnology 2002, 12, 545-550. [CrossRef]

2. Giménez, G.; Andriolo, J.L.; Janisch, D.; Cocco, C.; Picio, M.D. Cell size in trays for the production of strawberry plug transplants. Pesqui. Agropecu. Bras. 2009, 44, 726-729. [CrossRef]

3. Türkben, C. Propagation of strawberry plants in pots: Effect of runner order and rooting media. Int J. Biol. Sci. 2008, 2, 1-4.

4. Hokanson, S.C.; Takeda, F.; Enns, J.M.; Black, B.L. Influence of plant storage duration on strawberry runner tip viability and field performance. HortScience 2004, 39, 1596-1600. [CrossRef]

5. Saito, Y.; Imagawa, M.; Yabe, K.; Bantog, N.; Yamada, K.; Yamaki, S. Stimulation of rooting by exposing cuttings of runner plants to low temperatures to allow the raising of strawberry seedlings during summer. J. Jpn. Soc. Hortic. Sci. 2008, 77, 180-185. [CrossRef]

6. Massetani, F.; Savini, G.; Neri, D. Effect of rooting time, pot size and fertigation technique on strawberry plant architecture. J. Berry Res. 2014, 4, 217-224. [CrossRef]

7. Jia, H.; Hu, Y.; Fan, T.; Li, J. Hydrogen sulfide modulates actin-dependent auxin transport via regulating ABPs results in changing of root development in Arabidopsis. Sci. Rep. 2015, 5, 8251. [CrossRef]

8. Fang, T.; Cao, Z.; Li, J.; Shen, W.; Huang, L. Auxin-induced hydrogen sulfide generation is involved in lateral root formation in tomato. Plant Physiol. Bioch. 2014, 76, 44-51. [CrossRef]

9. Fang, T.; Li, J.; Cao, Z.; Chen, M.; Shen, W.; Huang, L. Heme oxygenase-1 is involved in sodium hydrosulfide-induced lateral root formation in tomato seedlings. Plant Cell Rep. 2014, 33, 969-978. [CrossRef]

10. Mei, Y.; Chen, H.; Shen, W.; Shen, W.; Huang, L. Hydrogen peroxide is involved in hydrogen sulfide-induced lateral root formation in tomato seedlings. BMC Plant Biol. 2017, 17, 162. [CrossRef]

11. Kou, N.; Xiang, Z.; Cui, W.; Li, L.; Shen, W. Hydrogen sulfide acts downstream of methane to induce cucumber adventitious root development. J. Plant Physiol. 2018, 228, 113-120. [CrossRef] [PubMed]

12. Hu, L.Y.; Hu, S.L.; Wu, J.; Li, Y.H.; Zheng, J.L.; Wei, Z.J.; Liu, J.; Wang, H.L.; Liu, Y.S.; Zhang, H. Hydrogen sulfide prolongs postharvest shelf life of strawberry and plays an antioxidative role in fruits. J. Agric. Food Chem. 2012, 60, 8684-8693. [CrossRef] [PubMed]

13. Chang, Z.; Jingying, S.; Liqin, Z.; Changle, L.; Qingguo, W. Cooperative effects of hydrogen sulfide and nitric oxide on delaying softening and decay of strawberry. Int. J. Agric. Biol. Eng. 2014, 7, 114-122.

14. Christou, A.; Manganaris, G.A.; Papadopoulos, I.; Fotopoulos, V. Hydrogen sulfide induces systemic tolerance to salinity and non-ionic osmotic stress in strawberry plants through modification of reactive species biosynthesis and transcriptional regulation of multiple defense pathways. J. Exp. Bot. 2013, 64, 1953-1966. [CrossRef] [PubMed]

15. Christou, A.; Filippou, P.; Manganaris, G.A.; Fotopoulos, V. Sodium hydrosulfide induces systemic thermotolerance to strawberry plants through transcriptional regulation of heat shock proteins and aquaporin. BMC Plant Biol. 2014, 14, 42. [CrossRef] [PubMed]

16. Fotopoulos, V.; Christou, A.; Antoniou, C.; Manganaris, G. Hydrogen sulphide: A versatile tool for the regulation of growth and defense responses in horticultural crops. J. Hort. Sci. Biotechnol. 2015, 90, 227-234. [CrossRef]

17. Husen, A.; Pal, M. Metabolic changes during adventitious root primordium development in Tectona grandis Linn. f. (teak) cuttings as affected by age of donor plants and auxin (IBA and NAA) treatment. New For. 2007, 33, 309-323. [CrossRef]

18. Husen, A. Stock-plant etiolation causes drifts in total soluble sugars and anthraquinones, and promotes adventitious root formation in teak (Tectona grandis L. f.) coppice shoots. Plant Growth Regul. 2008, 54, 13-21. [CrossRef]

19. Reza-Shahsavar, A. Endogenous soluble sugars, starch contents and phenolic compounds in easy-and difficult-to-root olive cuttings. J. Biol. Environ. Sci. 2010, 4, 83-86.

20. Haissig, B.E. Metabolic processes in adventitious rooting of cuttings. In New Root Formation in Plants and Cuttings; Springer: Dordrecht, The Netherlands, 1986; pp. 141-189.

21. Mohan, R.; Chui, E.A.; Biasi, L.A.; Soccol, C.R. Alternative in vitro propagation: Use of sugarcane bagasse as a low cost support material during rooting stage of strawberry Cv. Dover. Braz. Arch. Biol. Technol. 2005, 48, 37-42. [CrossRef] 
22. Chen, J.; Shang, Y.T.; Wang, W.H.; Chen, X.Y.; He, E.M.; Zheng, H.L.; Shangguan, Z. Hydrogen sulfide-mediated polyamines and sugar changes are involved in hydrogen sulfide-induced drought tolerance in Spinacia oleracea seedlings. Front. Plant Sci. 2016, 7, 1173. [CrossRef] [PubMed]

23. Li, S.W.; Leng, Y.; Feng, L.; Zeng, X.Y. Involvement of abscisic acid in regulating antioxidative defense systems and IAA-oxidase activity and improving adventitious rooting in mung bean (Vigna radiata (L.) Wilczek) seedlings under cadmium stress. Environ. Sci. Pollut. Res. 2014, 21, 525-537. [CrossRef] [PubMed]

24. Kose, C.; Erdal, S.; Kaya, O.; Atici, O. Comparative evaluation of oxidative enzyme activities during adventitious rooting in the cuttings of grapevine rootstocks. J. Sci. Food Agric. 2011, 91, 738-741. [CrossRef] [PubMed]

25. Elmongy, M.S.; Zhou, H.; Cao, Y.; Liu, B.; Xia, Y. The effect of humic acid on endogenous hormone levels and antioxidant enzyme activity during in vitro rooting of evergreen azalea. Sci. Hortic. 2018, 227, 234-243. [CrossRef]

26. Li, S.W.; Zeng, X.Y.; Leng, Y.; Feng, L.; Kang, X.H. Indole-3-butyric acid mediates antioxidative defense systems to promote adventitious rooting in mung bean seedlings under cadmium and drought stresses. Ecotox. Environ. Saf. 2018, 161, 332-341. [CrossRef]

27. Veal, E.; Day, A. Hydrogen Peroxide as a Signaling Molecule; Mary Ann Liebert, Inc.: New Rochelle, NY, USA, 2011.

28. Yang, W.; Zhu, C.; Ma, X.; Li, G.; Gan, L.; Ng, D.; Xia, K. Hydrogen peroxide is a second messenger in the salicylic acid-triggered adventitious rooting process in mung bean seedlings. PLoS ONE 2013, 8, e84580. [CrossRef]

29. Li, S.W.; Xue, L.; Xu, S.; Feng, H.; An, L. IBA-induced changes in antioxidant enzymes during adventitious rooting in mung bean seedlings: The role of $\mathrm{H}_{2} \mathrm{O}_{2}$. Environ. Exp. Bot. 2009, 66, 442-450. [CrossRef]

30. Li, C.; Bian, B.; Gong, T.; Liao, W. Comparative proteomic analysis of key proteins during abscisic acid-hydrogen peroxide-induced adventitious rooting in cucumber (Cucumis sativus L.) under drought stress. J. Plant Physiol. 2018, 229, 185-194. [CrossRef]

31. Zhao, Y.; Biggs, T.D.; Xian, M. Hydrogen sulfide $\left(\mathrm{H}_{2} \mathrm{~S}\right)$ releasing agents: Chemistry and biological applications. Chem. Commun. 2014, 50, 11788-11805. [CrossRef]

32. Nashef, A.S.; Osuga, D.T.; Feeney, R.E. Determination of hydrogen sulfide with 5,5'-dithiobis-(2-nitrobenzoic acid), n-ethylmaleimide, and parachloromercuribenzoate. Anal. Biochem. 1977, 79, 394-405. [CrossRef]

33. Loreto, F.; Velikova, V. Isoprene produced by leaves protects the photosynthetic apparatus against ozone damage, quenches ozone products, and reduces lipid peroxidation of cellular membranes. Plant Physiol. 2001, 127, 1781-1787. [CrossRef] [PubMed]

34. Xue, J.; Wang, S.; Zhang, P.; Zhu, F.; Ren, X.; Liu, C.; Zhang, X. On the role of physiological substances, abscisic acid and its biosynthetic genes in seed maturation and dormancy of tree peony (Paeonia ostii ‘Feng Dan'). Sci. Hortic. 2015, 182, 92-101. [CrossRef]

35. Manivannan, A.; Soundararajan, P.; Arum, L.S.; Ko, C.H.; Muneer, S.; Jeong, B.R. Blue LED light enhances growth phytochemical contents, and antioxidant enzyme activities of Rehmannia glutinosa cultured in vitro. Hortic. Environ. Biotechnol. 2015, 56, 105-113. [CrossRef]

36. Jin, Z.; Pei, Y. Physiological implications of hydrogen sulfide in plants: Pleasant exploration behind its unpleasant odour. Oxid. Med. Cell. Longev. 2015, 2015, 397502. [CrossRef] [PubMed]

37. Lin, Y.T.; Li, M.Y.; Cui, W.T.; Lu, W.; Shen, W.B. Haem oxygenase-1 is involved in hydrogen sulfide-induced cucumber adventitious root formation. J. Plant Growth Regul. 2012, 31, 519-528. [CrossRef]

38. Sairanen, I.; Novak, O.; Pencik, A.; Ikeda, Y.; Jones, B.; Sandberg, G.; Ljung, K. Soluble carbohydrates regulate auxin biosynthesis via PIF proteins in Arabidopsis. Plant Cell 2012, 24, 4907-4916. [CrossRef]

39. Buettner, G.R.; Ng, C.F.; Wang, M.; Rodgers, V.G.J.; Schafer, F.Q. A new paradigm: Manganese superoxide dismutase influences the production of $\mathrm{H}_{2} \mathrm{O}_{2}$ in cells and thereby their biological state. Free Radical Biol. Med. 2006, 41, 1338-1350. [CrossRef]

40. Aghdam, M.S.; Mahmoudi, R.; Razavi, F.; Rabiei, V.; Soleimani, A. Hydrogen sulfide treatment confers chilling tolerance in hawthorn fruit during cold storage by triggering endogenous $\mathrm{H}_{2} \mathrm{~S}$ accumulation, enhancing antioxidant enzymes activity and promoting phenols accumulation. Sci. Hortic. 2018, 238, 264-271. [CrossRef] 
41. Min, Y.; Qin, B.P.; Ping, W.; Li, M.L.; Chen, L.L.; Chen, L.T.; Sun, A.Q.; Wang, Z.L.; Yin, Y.P. Foliar application of sodium hydrosulfide (NaHS), a hydrogen sulfide $\left(\mathrm{H}_{2} \mathrm{~S}\right)$ donor, can protect seedlings against heat stress in wheat (Triticum aestivum L.). J. Integr. Agric. 2016, 15, 2745-2758.

42. Da Silva, C.J.; Fontes, E.P.B.; Modolo, L.V. Salinity-induced accumulation of endogenous $\mathrm{H}_{2} \mathrm{~S}$ and $\mathrm{NO}$ is associated with modulation of the antioxidant and redox defense systems in Nicotiana tabacum L. cv. Havana. Plant Sci. 2017, 256, 148-159. [CrossRef]

43. Li, Z.G.; Gong, M.; Xie, H.; Yang, L.; Li, J. Hydrogen sulfide donor sodium hydrosulfide-induced heat tolerance in tobacco (Nicotiana tabacum L.) suspension cultured cells and involvement of $\mathrm{Ca}^{2+}$ and calmodulin. Plant Sci. 2012, 185, 185-189. [CrossRef] [PubMed]

44. Filippou, P.; Tanou, G.; Molassiotis, A.; Fotopoulos, V. Plant acclimation to environmental stress using priming agents. In Plant Acclimation to Environmental Stress; Springer: New York, NY, USA, 2013; pp. 1-27.

45. He, H.; Li, Y.; He, L.F. The central role of hydrogen sulfide in plant responses to toxic metal stress. Ecotox. Environ. Saf. 2018, 157, 403-408. [CrossRef] [PubMed]

(C) 2020 by the authors. Licensee MDPI, Basel, Switzerland. This article is an open access article distributed under the terms and conditions of the Creative Commons Attribution (CC BY) license (http://creativecommons.org/licenses/by/4.0/). 